\title{
Stable oxygen-hydrogen isotopes reveal water use strategies of Tamarix taklamakanensis in the Taklimakan Desert, China
}

\author{
DONG Zhengwu ${ }^{1,2,3,4}$, LI Shengyu ${ }^{1 *}$, ZHAO Ying ${ }^{5}$, LEI Jiaqiang1, WANG Yongdong ${ }^{1}$, LI \\ Congjuan ${ }^{1}$ \\ ${ }^{1}$ Xinjiang Institute of Ecology and Geography, Chinese Academy of Sciences, Urumqi 830011, China; \\ ${ }^{2}$ College of Resources and Environment Science, Xinjiang University, Urumqi 830046, China; \\ ${ }^{3}$ College of Life Science, Xinjiang Normal University, Urumqi 830054, China; \\ ${ }^{4}$ University of Chinese Academy of Sciences, Beijing 100049, China; \\ ${ }^{5}$ College of Resources and Environmental Engineering, Ludong University, Yantai 264025, China
}

\begin{abstract}
Tamarix taklamakanensis, a dominant species in the Taklimakan Desert of China, plays a crucial role in stabilizing sand dunes and maintaining regional ecosystem stability. This study aimed to determine the water use strategies of T. taklamakanensis in the Taklimakan Desert under a falling groundwater depth. Four typical T. taklamakanensis nabkha habitats (sandy desert of Tazhong site, saline desert-alluvial plain of Qiemo site, desert-oasis ecotone of Qira site and desert-oasis ecotone of Aral site) were selected with different climate, soil, groundwater and plant cover conditions. Stable isotope values of hydrogen and oxygen were measured for plant xylem water, soil water (soil depths within $0-500 \mathrm{~cm}$ ), snowmelt water and groundwater in the different habitats. Four potential water sources for T. taklamakanensis, defined as shallow, middle and deep soil water, as well as groundwater, were investigated using a Bayesian isotope mixing model. It was found that groundwater in the Taklimakan Desert was not completely recharged by precipitation, but through the river runoff from snowmelt water in the nearby mountain ranges. The surface soil water content was quickly depleted by strong evaporation, groundwater depth was relatively shallow and the height of T. taklamakanensis nabkha was relatively low, thus $T$. taklamakanensis primarily utilized the middle $(23 \% \pm 1 \%)$ and deep $(31 \% \pm 5 \%)$ soil water and groundwater $(36 \% \pm 2 \%)$ within the sandy desert habitat. T. taklamakanensis mainly used the deep soil water $(55 \% \pm 4 \%)$ and a small amount of groundwater $(25 \% \pm 2 \%)$ within the saline desert-alluvial plain habitat, where the soil water content was relatively high and the groundwater depth was shallow. In contrast, within the desert-oasis ecotone in the Qira and Aral sites, T. taklamakanensis primarily utilized the deep soil water $(35 \% \pm 1 \%$ and $38 \% \pm 2 \%$, respectively) and may also use groundwater because the height of T. taklamakanensis nabkha was relatively high in these habitats and the soil water content was relatively low, which is associated with the reduced groundwater depth due to excessive water resource exploitation and utilization by surrounding cities. Consequently, T. taklamakanensis showed distinct water use strategies among the different habitats and primarily depended on the relatively stable water sources (deep soil water and groundwater), reflecting its adaptations to the different habitats in the arid desert environment. These findings improve our understanding on determining the water sources and water use strategies of $T$. taklamakanensis in the Taklimakan Desert.
\end{abstract}

Keywords: Tamarix taklamakanensis; water use strategies; stable isotopes; Bayesian isotope mixing model; deep soil water; groundwater; Taklimakan Desert

*Corresponding author: LI Shengyu (E-mail: oasis@ms.xjb.ac.cn)

Received 2019-05-08; revised 2019-12-10; accepted 2019-12-15

C Xinjiang Institute of Ecology and Geography, Chinese Academy of Sciences, Science Press and Springer-Verlag GmbH Germany, part of Springer Nature 2020 
Citation: DONG Zhengwu, LI Shengyu, ZHAO Ying, LEI Jiaqiang, WANG Yongdong, LI Congjuan. 2020. Stable oxygen-hydrogen isotopes reveal water use strategies of Tamarix taklamakanensis in the Taklimakan Desert, China. Journal of Arid Land, 12(1): 115-129. https://doi.org/10.1007/s40333-020-0051-4

\section{Introduction}

Water is an indispensable factor for plant growth, vegetation distribution and community composition (Rosenthal et al., 2005; Zhou et al., 2013; Zhang et al., 2018). In the desert ecosystem, water is extraordinarily valuable and has a decisive impact on the survival and distribution of plants. In addition, precipitation and groundwater are the primary water sources in the desert ecosystem and groundwater plays a vital role in shaping plant adaptations because precipitation is very limited and unpredictable (Dai et al., 2015). In the past decades, it was commonly accepted that soil moisture was the remains of the last precipitation event in the desert environment (Evaristo et al., 2016). However, previous studies have indicated that in shifting sand dunes, rainfall of $<13.40 \mathrm{~mm}$ cannot be utilized by plants as it may be completely evaporated before infiltrating into the deep soil layer (Chen et al., 2003; Liu et al., 2006). Furthermore, soil water content (SWC) in the desert ecosystem is extremely variable in both space and time (Zhou et al., 2017). Therefore, desert plants are generally under chronic or periodic water-deficit conditions. Perennial plants have to adjust their water use strategies to survive and meet their growth and metabolism requirements, and their roots must acquire sufficient groundwater or residual soil water to tolerate prolonged drought (Tiemuerbieke et al., 2018). Likewise, desert plants are accompanied by high vulnerability to climatic change in the extreme habitats. Moreover, climate change and over-exploitation of groundwater could severely injure desert species and affect the frail ecosystem (Dai et al., 2015; Zhang et al., 2018). Therefore, it is critical to obtain a high level of comprehension about the water use strategies of plants in the desert environment.

The Taklimakan Desert is the largest shifting sand desert in China. Sand dunes throughout the desert were formed in alignment by aeolian sand. The desert has been severely affected by human activities and is, thus, highly susceptible to changes in water availability. As the dominant species in this desert, Tamarix taklamakanensis plays a crucial role in stabilizing sand dunes and maintaining the function and structure of the desert ecosystem (Zhao et al., 2011). In the Taklimakan Desert, a long-term accumulation of the alternate sand layers and litter layers around T. taklamakanensis (Muhtar et al., 2002; Xia et al., 2004) results in the formation of a specific biogeographic unit called the T. taklamakanensis nabkha, with the heights ranging from 3 to $15 \mathrm{~m}$ and lengths from 5 to $50 \mathrm{~m}$ (long axis) (Zhao et al., 2011). T. taklamakanensis nabkha is mainly distributed in the lower reaches of the Tarim River and the hinterland of the Taklimakan Desert (Zhao and Xia, 2011). However, degeneration and extinction of T. taklamakanensis nabkha have occurred in the desert ecosystem as a result of human activities and climate change, and this may directly affect the stability of the local desert ecosystem (Zhao and Xia, 2011). Currently, little is known about the water use strategies of $T$. taklamakanensis at the T. taklamakanensis nabkha locations in the desert ecosystem. A clear understanding of the water sources used by T. taklamakanensis will help us to assess the effects of human activities and climate change on the local ecosystem.

Stable isotope analysis is a powerful tool that has been extensively utilized to identify the water sources of plants (Schachtschneider and February, 2010; Dai et al., 2015; Evaristo et al., 2016; Zhou et al., 2017; Tiemuerbieke et al., 2018). Due to the influences of physical and climatic factors, different water sources in nature have diverse isotope signatures (Craig, 1961; Schachtschneider and February, 2010; Tiemuerbieke et al., 2018), and the stable isotope fractionation is not generally observed in the water uptake processes of root systems from soils (Evaristo et al., 2016). Thus, the stable isotope information of potential water sources can be reflected by the isotope composition of plant xylem water (Si et al., 2014; Tiemuerbieke et al., 2018). Plant water sources can be identified by comparing the isotope ratios of plant xylem water to the isotope concentrations of all potential water sources (Dai et al., 2015; Wu et al., 2016; Tiemuerbieke et al., 2018). In China, the water sources and water use strategies of Tamarix ramosissima, Tamarix laxa and Tamarix chinensis have previously been explored in the Gurbantunggut Desert, Badain Jaran Desert, Heihe River Basin and 
Dunhuang Oasis by many researchers (Cui et al., 2015; Sun et al., 2016; Wu et al., 2016; Zhang et al., 2018), and their findings indicated that the growth of these plants relies on water sources from different soil depths (Wu et al., 2014; Cui et al., 2015; Zhang et al., 2018). However, previous studies on water use of $T$. ramosissima have mainly focused on the desert riparian belt, and the upper and lower reaches of the Tarim River Basin (Wang et al., 2017; Zhou et al., 2017). Some studies have observed that $T$. ramosissima primarily used groundwater in the Tarim River Basin, and also utilized deep soil water below $200 \mathrm{~cm}$ (Li et al., 2009; Zhao and Xia, 2011). Nevertheless, because of the influences of environmental factors (e.g., precipitation, groundwater depth and micro-topography) and human activities in the different habitats of T. taklamakanensis, the understanding of potential water sources and water use strategies of $T$. taklamakanensis is severely limited. This is particularly the case in the desert environment, where the water use strategies of T. taklamakanensis within the $T$. taklamakanensis nabkha represent a critical research gap, even though the habitats of $T$. taklamakanensis are crucial in our comprehending of the chronically adaptive mechanisms of desert plants to the spatial pattern change of soil water.

The aim of our study was to determine the water sources and water use strategies of $T$. taklamakanensis in four habitats (sandy desert of Tazhong, saline desert-alluvial plain of Qiemo, desert-oasis ecotone of Qira and desert-oasis ecotone of Aral) in the center and fringe of the Taklimakan Desert, using the stable isotope approach. Given the known differences in micro-climate, soil and groundwater depth in the different habitats (Zhao and Xia, 2011; Zeng and Song, 2013), our first hypothesis was that $T$. taklamakanensis has different water use strategies within different habitats. Likewise, considering that aridity is a typical feature in the Taklimakan Desert and plant roots in the surface soil layer may be inactive because of the long-lasting periods of low SWC, our second hypothesis was that this species mainly utilizes middle and deep soil water and/or groundwater, especially for the habitats with extremely arid climate conditions.

\section{Materials and methods}

\subsection{Study sites}

The Taklimakan Desert is located in Northwest China and covers an area of $33.76 \times 10^{4} \mathrm{~km}^{2}$ $\left(37^{\circ}-41^{\circ} \mathrm{N}, 77^{\circ}-90^{\circ} \mathrm{E}\right.$ ), with approximately $85 \%$ of its environment composed of shifting sand (Sun and Liu, 2006). It is known to be a significant sand-dust source area with the frequency of dust events being up to $100 \mathrm{~d} / \mathrm{a}$ (Wang et al., 2005). The mean annual precipitation ranges from 24.00 to 65.30 $\mathrm{mm}$ and the mean annual evaporation extends up to $3000.00 \mathrm{~mm}$, which is about $30-140$ times larger than the amount of precipitation. Precipitation occurring in summer quickly evaporates from the surface soil layers under high evaporation, resulting in decreased surface soil water. Tributaries and transitional rivers, formed by the snowmelt water from the mountains over the summer, permit the formation of oases along the desert fringe (Bruelheide et al., 2003). Since there is no rainy season, typically no annual plants grow in this region. The predominant species are mainly shrubs, including T. taklamakanensis, Populus euphratica, Karelinia caspia and Alhagi sparsifolia.

The formation and development of T. taklamakanensis nabkha are mainly affected by wind erosion and hydraulic erosion. Four sampling sites with different micro-climates, soil types and vegetation cover conditions were selected to cover the typical range of T. taklamakanensis nabkha habitats within the Taklimakan Desert (Fig. 1; Table 1; Dong et al., 2018). Sampling site A was located in the central Taklimakan Desert, near the Taklimakan Desert Research Station of Xinjiang Institute of Ecology and Geography, Chinese Academy of Sciences. The plant cover of $T$. taklamakanensis nabkha was approximately $20 \%$ and the surface of T. taklamakanensis nabkha was characterized by scattered shifting sand. Sampling site B was located near the Qiemo County in the southeastern fringe of the Taklimakan Desert along the desert highway, which is the transition zone between alluvial plain and desert. The plant cover of T. taklamakanensis nabkha was $50 \%$ and the saline soil and strong evaporation in summer had contributed to the formation of salt crust on the soil surface. Sampling site C was situated in the southern fringe of the Taklimakan Desert, with the distance of about $10 \mathrm{~km}$ from the Qira County. This region is a desert-oasis ecotone. The plant cover 
of T. taklamakanensis nabkha was 30\%-35\% and the soil surface was dominated by shifting sand with light salinization. Sampling site D was located near the city of Aral in the northern fringe of the Taklimakan Desert. This region is also a desert-oasis ecotone. The plant cover of T. taklamakanensis nabkha was $40 \%-45 \%$ and the soil surface was moderately salinized and covered by a thin salt crust (Table 1). In the four sampling sites, the soil was mainly aeolian sand in texture.

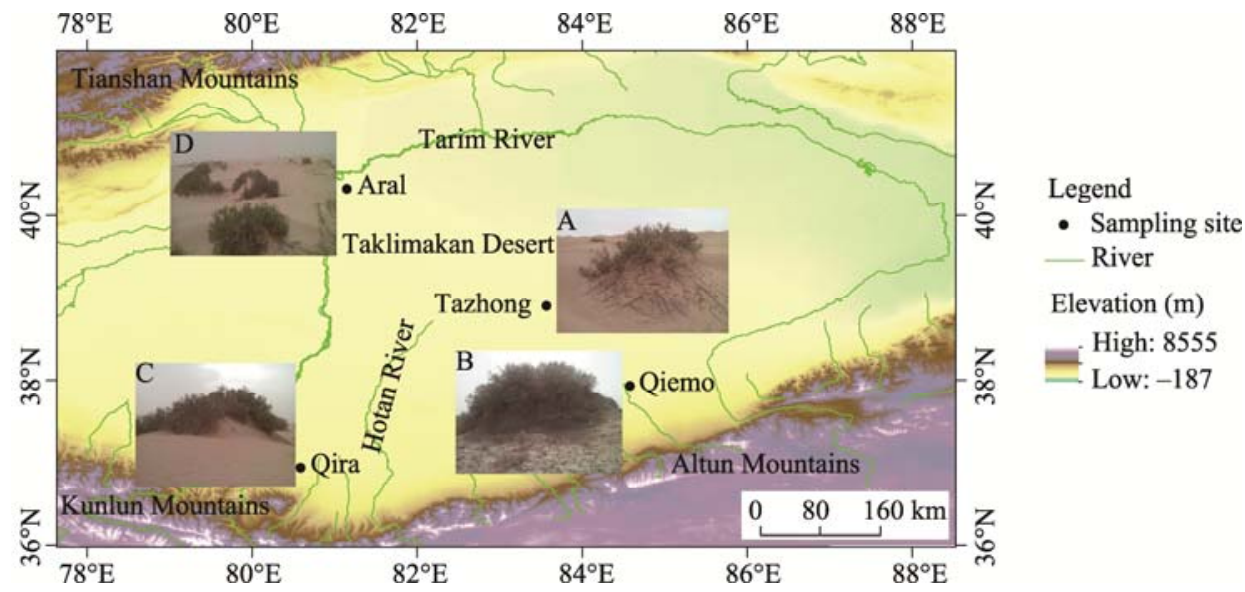

Fig. 1 Location of sampling sites in the Taklimakan Desert. A, B, C and D represent the four sampling sites of Tamarix taklamakanensis habitats. A, sandy desert of Tazhong site; B, saline desert-alluvial plain of Qiemo site; C, desert-oasis ecotone of Qira site; D, desert-oasis ecotone of Aral site. It should be noted that only the important rivers are marked in the figure.

At each sampling site, four mature individual T. taklamakanensis nabkhas were selected, and the adjacent sampling nabkhas (about $500 \mathrm{~m}$ apart) were considered representative of middle-sized nabkha. At all the sampling sites, the average height, length and width of $T$. taklamakanensis nabkhas were $3.13( \pm 0.53), 7.37( \pm 0.66)$ and $5.72( \pm 0.46) \mathrm{m}$, respectively (Table 1$)$.

Table 1 Meteorological and habitat data of the sampling sites within the Taklimakan Desert

\begin{tabular}{|c|c|c|c|c|c|c|c|c|c|c|}
\hline \multirow[b]{2}{*}{ Site } & \multirow[b]{2}{*}{ Location } & \multirow[b]{2}{*}{$\begin{array}{c}\text { Groundwater } \\
\text { depth }(\mathrm{m})\end{array}$} & \multirow[b]{2}{*}{ Soil surface } & \multicolumn{4}{|c|}{ Tamarix taklamakanensis nabkha } & \multirow{2}{*}{$\begin{array}{l}\text { AMT } \\
\left({ }^{\circ} \mathrm{C}\right)\end{array}$} & \multirow{2}{*}{$\begin{array}{l}\text { MAP } \\
(\mathrm{mm})\end{array}$} & \multirow{2}{*}{$\begin{array}{c}\text { MAEP } \\
(\mathrm{mm})\end{array}$} \\
\hline & & & & $\begin{array}{c}\text { Plant cover } \\
(\%)\end{array}$ & $\begin{array}{l}\text { Height } \\
(\mathrm{m})\end{array}$ & $\begin{array}{l}\text { Length } \\
(\mathrm{m})\end{array}$ & $\begin{array}{c}\text { Width } \\
(\mathrm{m})\end{array}$ & & & \\
\hline Tazhong & $\begin{array}{l}39.06^{\circ} \mathrm{N} \\
83.67^{\circ} \mathrm{E}\end{array}$ & $5.0-6.0$ & $\begin{array}{l}\text { Aeolian sandy } \\
\text { soil }\end{array}$ & 20 & 2.64 & 6.71 & 5.37 & 11.82 & 25.11 & 3559.60 \\
\hline Qiemo & $\begin{array}{l}38.03^{\circ} \mathrm{N} \\
84.68^{\circ} \mathrm{E}\end{array}$ & $4.5-5.5$ & $\begin{array}{l}\text { Salt crust and } \\
\text { aeolian sandy } \\
\text { soil }\end{array}$ & 50 & 3.27 & 7.45 & 5.89 & 10.68 & 27.97 & 2360.60 \\
\hline Qira & $\begin{array}{l}37.04^{\circ} \mathrm{N} \\
80.69^{\circ} \mathrm{E}\end{array}$ & $11.0-16.0$ & $\begin{array}{l}\text { Shifting sand } \\
\text { with light } \\
\text { salinization }\end{array}$ & $30-35$ & 3.53 & 7.87 & 6.10 & 12.52 & 41.67 & 2790.20 \\
\hline Aral & $\begin{array}{l}40.42^{\circ} \mathrm{N} \\
81.25^{\circ} \mathrm{E}\end{array}$ & $8.0-10.0$ & $\begin{array}{l}\text { Slight crust and } \\
\text { moderately } \\
\text { salinization }\end{array}$ & $40-45$ & 3.08 & 7.23 & 5.59 & 10.97 & 51.54 & 1813.20 \\
\hline
\end{tabular}

Note: AMT, annual mean temperature; MAP, mean annual precipitation; MAEP, mean annual evaporation. The climatic data are referred from Gong et al. (2011), Fan et al. (2013), and Zeng and Song (2013).

\subsection{Sample collection and analysis}

Field sampling was conducted in July 2017. It should be noted that no precipitation events occurred during the sampling period. In general, the material was sampled at mid-day. In each sampling site, four soil cores were collected from the four T. taklamakanensis nabkhas using a handheld auger. Finally, a total of 16 soil cores were sampled at each sampling site. Based on our prior knowledge of soil water isotope along the soil profile (Zhao and Xia, 2011), we collected soil samples within the 0-500 cm depth at an interval of $20 \mathrm{~cm}$. Each soil sample was separated into two subsamples: one subsample was packaged immediately in an airtight bottle and refrigerated at $-20^{\circ} \mathrm{C}$ until isotope analysis, and the other subsample was sealed in soil tins for SWC analysis by the oven-drying method. Soil particle size fractions were measured using a laser particle sizer (Mastersizer 2000, 
Malvern Instruments Ltd., Worcestershire, UK). According to the US classification standards, we classified the soil particle size into four types: clay $(<0.002 \mathrm{~mm})$, silt $(0.002-0.050 \mathrm{~mm})$, very fine sand $(0.050-0.100 \mathrm{~mm})$ and fine sand $(0.100-0.250 \mathrm{~mm})$.

Plant samples were collected on the same days as the soil sample collection. Six twigs of $T$. taklamakanensis were sampled from each T. taklamakanensis nabkha. To avoid isotope fractionation of plant xylem water, we sampled the completely suberized twigs (diameter: $0.3-0.5 \mathrm{~cm}$; length: $4.0-5.0 \mathrm{~cm}$ ) for the extraction of plant xylem water. As soon as sampling, the green tissues, including all leaves and green bark, were removed quickly from the stems. Then, all plant samples were promptly put into the screw-cap glass bottles, sealed with parafilm and stored in a freezer $\left(-20^{\circ} \mathrm{C}\right)$ until isotope analysis.

Groundwater samples were obtained from the nearby wells approximately $10-20 \mathrm{~km}$ from each site. To reflect the potential contribution of snowmelt water to the groundwater isotope signature, we collected snowmelt water from bedrock canyon in the Tianshan Mountains and Kunlun Mountains. Snowmelt water is representative of the perennial precipitation in the Taklimakan Desert. Both groundwater and snowmelt water samples were rapidly put into glass vials and sealed with parafilm and stored in a fridge at $4^{\circ} \mathrm{C}$ for later isotope analysis.

\subsection{Stable isotope analysis}

We used deuterium $\left({ }^{2} \mathrm{H}\right)$ and oxygen $\left({ }^{18} \mathrm{O}\right)$ isotope values of soil water and groundwater to describe the potential water sources, which were compared with the $\delta^{2} \mathrm{H}$ and $\delta^{18} \mathrm{O}$ values of plant xylem water. Soil water and plant xylem water were extracted using a cryogenic vacuum distillation apparatus (PicarroL2120-I, USA) (Evaristo et al., 2016). Plant xylem water, soil water, groundwater and snowmelt water samples were filtered using $0.22-\mu \mathrm{m}$ pore size filters and each sample was pipetted into a small screw-cap glass vial, sealed with parafilm and refrigerated at $2{ }^{\circ} \mathrm{C}$.

The liquid water isotope analyzer (DLT-100, Los Gatos Research Inc., Mountain View, USA) was utilized for stable isotope measurements. The analytical precision of individual measurements was $\pm 0.25 \%$ and $\pm 1.00 \%$ for $\delta^{18} \mathrm{O}$ and $\delta^{2} \mathrm{H}$, respectively. The stable isotope values can be expressed as:

$$
\delta\left({ }^{2} \mathrm{H},{ }^{18} \mathrm{O}\right)(\%)=\left(\frac{\mathrm{R}_{\text {sample }}}{\mathrm{R}_{\text {standard }}}-1\right) \times 1000 \%,
$$

where $\mathrm{R}_{\text {sample }}$ and $\mathrm{R}_{\text {standard }}$ are the stable isotope values (molar ratios of ${ }^{2} \mathrm{H}: \mathrm{H}$ and ${ }^{18} \mathrm{O}:{ }^{16} \mathrm{O}$ ) of the sample and the standard water (standard mean ocean water), respectively (Dawson et al., 2002). Given the low water content, the stable isotope values of plant xylem water and soil water may be erroneous because of the organic contamination from methanol and ethanol. Thus, to eliminate the spectral contamination, we corrected the stable isotope values of plant xylem water and soil water by a standard curve (Schultz et al., 2011).

\subsection{Classification of water sources}

A Bayesian isotope mixing model was used for the identification of plant water sources in the different habitats. The Bayesian isotope mixing model takes into account both $\delta^{18} \mathrm{O}$ and $\delta^{2} \mathrm{H}$ and the results are generally more robust. This model utilizes the Bayesian framework to identify the proportional contribution of each source to a mixture. The Bayesian isotope mixing model has been implemented in the software package SIAR (Stable Isotope Analysis in R) (Parnell et al., 2010), which was applied to determine the potential water sources that may contribute to plant xylem water.

Based on the similarities in the $\delta^{18} \mathrm{O}$ and $\delta^{2} \mathrm{H}$ values of soil water and the SWC within each soil depth in addition to the $\delta^{18} \mathrm{O}$ and $\delta^{2} \mathrm{H}$ values of plant xylem water, we classified the four potential sources of plant xylem water when running the Bayesian isotope mixing model. The $\delta^{18} \mathrm{O}$ and $\delta^{2} \mathrm{H}$ values for each soil depth were determined by the SWC-weighted mean approach (Wu et al., 2016) and soil water was categorized as follows: (1) shallow soil water $(0-200 \mathrm{~cm})$, which was the most unstable and $\delta^{18} \mathrm{O}$ and $\delta^{2} \mathrm{H}$ values varied significantly with depths; (2) middle soil water (200-400 $\mathrm{cm}$ ), which had lower $\delta^{18} \mathrm{O}$ and $\delta^{2} \mathrm{H}$ values with relatively weak changes; (3) deep soil water $(400-500 \mathrm{~cm})$, which had relatively consistent isotope composition and SWC with no significant 
differences among depths; and (4) groundwater, which had relatively constant $\delta^{18} \mathrm{O}$ and $\delta^{2} \mathrm{H}$ values.

\subsection{Data analysis}

Meteorological data were obtained from the Meteorological Information Center of Xinjiang and China Meteorological Data Network (http://data.cma.cn/data/weatherB-k.html). All statistical analyses were performed using SAS 9.2 (North Carolina, USA). Tukey's test (t-test) was used to evaluate the differences in isotope compositions of soil water, groundwater and plant xylem water obtained from each sampling site $(P<0.05)$. The relationships between $\delta^{18} \mathrm{O}$ and $\delta^{2} \mathrm{H}$ were established by using a linear regression model. Figures were plotted using the software Origin 2017 (OriginLab Corp., Northampton, USA).

\section{Results and discussion}

\subsection{Climate characteristics of the sampling sites}

The monthly mean temperature was typically lowest in January and highest in July for all sampling sites (Fig. 2). The precipitation mainly occurred between May and August, with approximately $80 \%-90 \%$ of the annual totals in the Tazhong, Qiemo and Qira sites. Approximately $90 \%$ of the annual precipitation occurred from May to October in the Aral site. Mean annual evaporation was highest in the Tazhong site, followed by Qira site, while Qiemo and Aral sites had relatively low amounts of evaporation. In the Tazhong site, the plant cover was very low due to the limited precipitation and intensive evaporation (Li et al., 2015). Nevertheless, in the Qira and Aral sites, precipitation was relatively high and evaporation was relatively low compared to the other two sites, and thus the plant cover was relatively high (Table 1). In the Qiemo site, precipitation was very low and the plant cover was relatively high. Plants such as Phragmites australis and Halostachys caspica were also observed in this site, which may be related to the flood alluvium in summer.
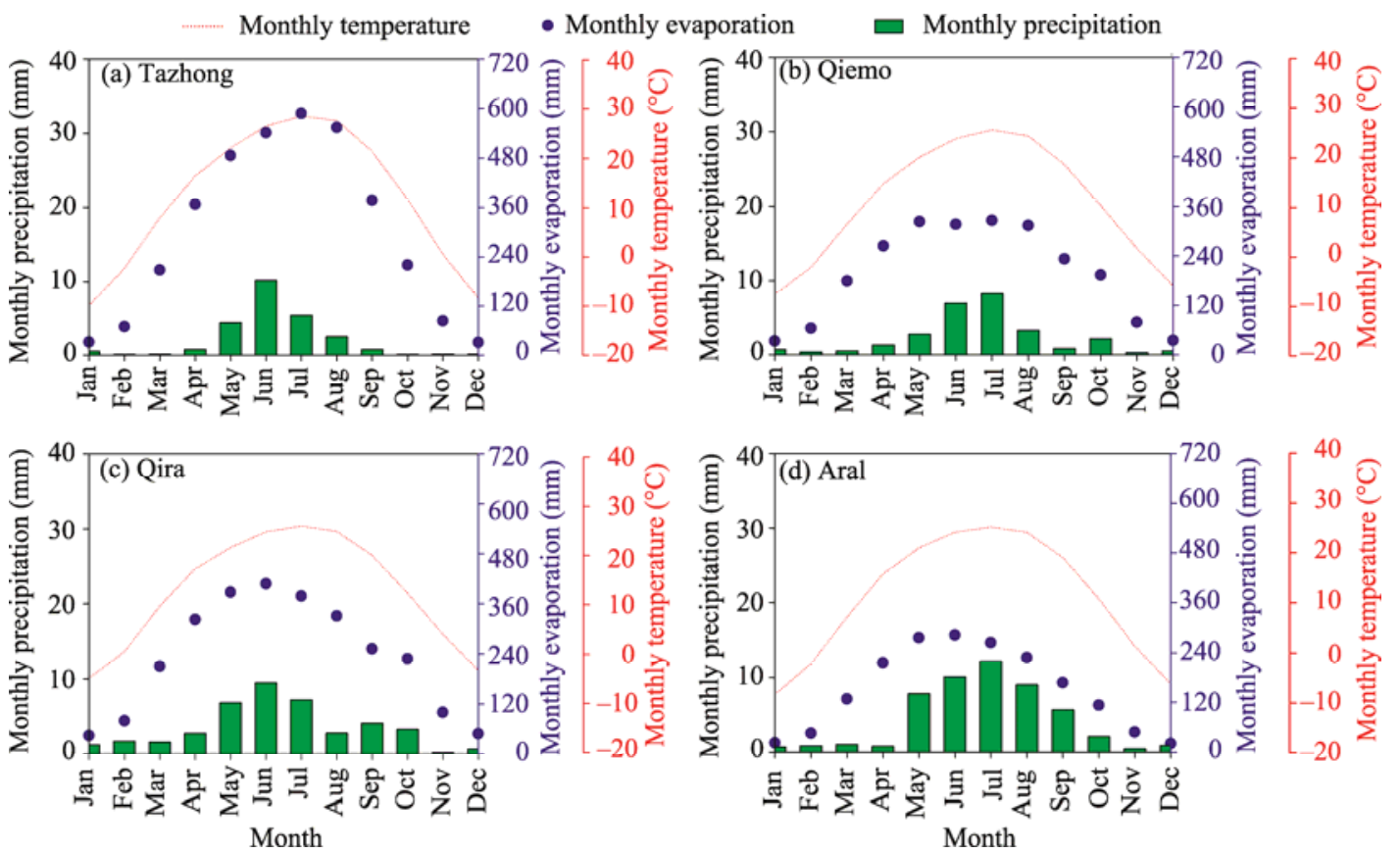

Fig. 2 Monthly precipitation, evaporation and air temperature in the Tazhong (a), Qiemo (b), Qira (c) and Aral (d) sites. The values represent monthly means during 1997-2015 in the Tazhong site and during 1965-2015 in the Qiemo, Qira and Aral sites.

\subsection{SWC and stable isotope values of soil water}

In the extremely dry desert ecosystem, the SWC is very low and water movement is affected by climate factors, soil properties and groundwater (Li et al., 2010). Previous studies have indicated that 
rainfall of around $15.00 \mathrm{~mm}$ may be entirely evaporated by about $20 \mathrm{~d}$ after the rainfall event under arid climate conditions, therefore infiltrated water cannot be completely enclosed by the sand layer and stored in soil for a long term (Liu et al., 2006; Li et al., 2010). In our study sites, the monthly precipitation was less than $12.00 \mathrm{~mm}$ (Fig. 2), and a single precipitation event seldom exceeded $10.00 \mathrm{~mm}$, indicating that the SWC was not fully derived from the precipitation (Si et al., 2014). Thus, we suggest that the influence of precipitation on the SWC is very small in the study sites. The soil in the T. taklamakanensis nabkhas was mainly composed of silt and sand (Fig. 3), and this kind of soil texture may be beneficial for a single large amount of rainfall to rapidly infiltrate into the soil and to replenish deep soil water in the Taklimakan Desert. Therefore, the SWC was affected by the factors such as soil texture and groundwater (Figs. 3 and 4a; Si et al., 2014; Cui et al., 2015).

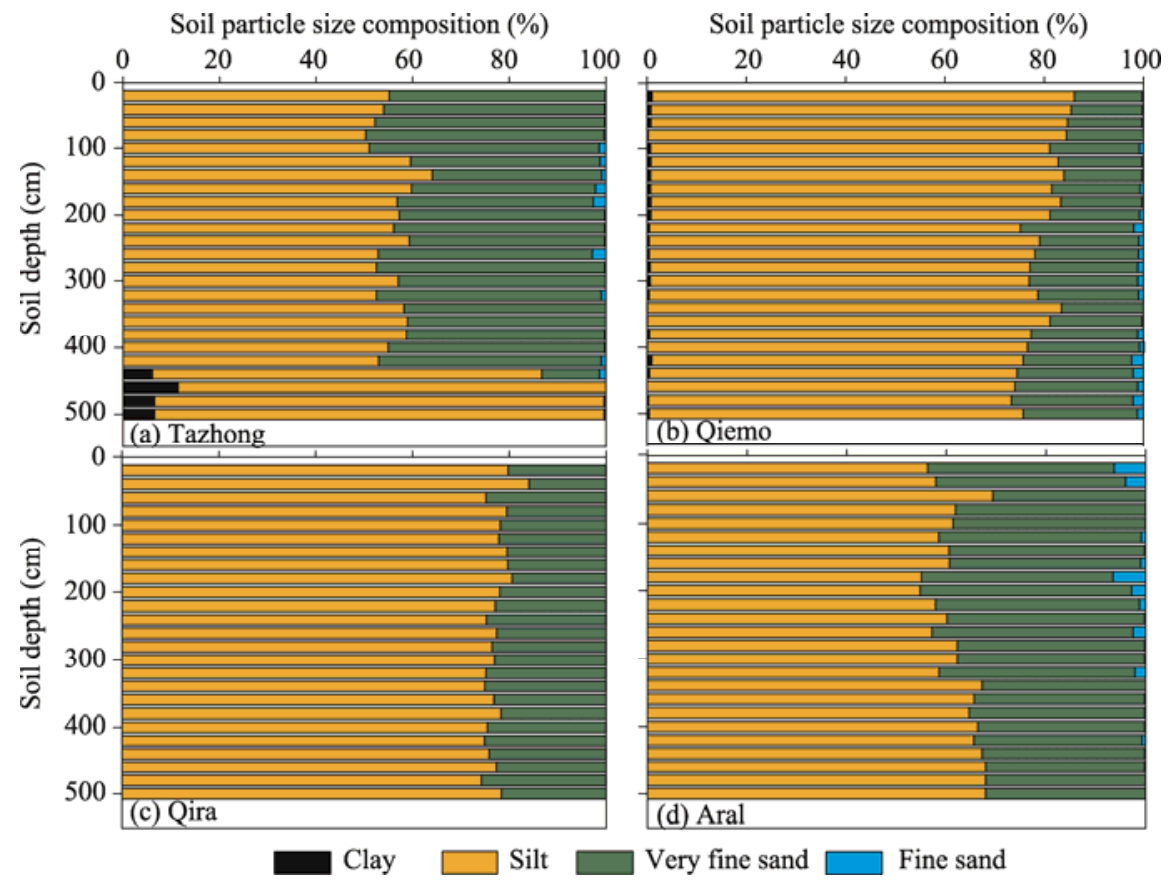

Fig. 3 Vertical distributions of soil particle size composition for the T. taklamakanensis nabkhas in the Tazhong (a), Qiemo (b), Qira (c) and Aral (d) sampling sites. Soil particle size composition was described in terms of the percentages of clay $(<0.002 \mathrm{~mm})$, silt $(0.002-0.050 \mathrm{~mm})$, very fine sand $(0.050-0.100 \mathrm{~mm})$ and fine sand $(0.100-0.250 \mathrm{~mm})$.

The SWC increased with soil depth for the T. taklamakanensis nabkhas in all sampling sites (Fig. 4a). In the Tazhong site, the SWC values within the 0-400 cm soil depth were extremely low, which could be attributed primarily to the sparse precipitation and strong evaporation within this region (Fig. 2). In the Qiemo site, the SWC values within the $0-400 \mathrm{~cm}$ soil depth were significantly lower than those within the $400-500 \mathrm{~cm}$ soil depth $(P<0.05)$. In addition, the plant cover was as high as $50 \%$ in the T. taklamakanensis nabkhas and the soil surface has a salt crust, resulting in the SWC significantly higher in the Qiemo site than in the other three sites $(P<0.05)$. Besides, in the $0-400 \mathrm{~cm}$ soil depth, the clay content in the Qiemo site was significantly higher than those in the other three sites $(P<0.05)$, which can be attributed to the relatively good water retention capabilities in the Qiemo site (Figs. 3 and 4a). In the Qira site, the upper soil layer $(0-200 \mathrm{~cm})$ was affected by strong evaporation, resulting in the low SWC values. The SWC values within the $200-400 \mathrm{~cm}$ soil depth exhibited no significant differences in the 400-500 cm soil depth $(P>0.05)$. In the Aral site, the SWC values showed no significant variations within the $0-500 \mathrm{~cm}$ soil depth $(P>0.05)$ and were significantly different from those in the other three sites.

Previous studies have demonstrated the enrichment of the heavy isotopes in the shallow soil water relative to the deep soil water and groundwater because of soil surface evaporation (Gat et al., 2007; Zhang et al., 2018). It should be noted that soil water was not extracted from the $0-80 \mathrm{~cm}$ soil depth 
in the Tazhong site and from the $0-20 \mathrm{~cm}$ soil depth in the Aral site due to the extreme low SWC in these soil layers. In the four study sites, evaporation most likely caused the enrichment of $\delta^{2} \mathrm{H}$ and $\delta^{18} \mathrm{O}$ in the shallow soil water $(0-200 \mathrm{~cm}$ depth; Figs. $4 \mathrm{~b}$ and $\mathrm{c})$. With increased soil depth, the influence of evaporation would be reduced. The isotope values of soil water in the $200-400 \mathrm{~cm}$ soil depth displayed relatively weak variations, and the values below the $400 \mathrm{~cm}$ soil depth showed no significant variations in each sampling site (Figs. 4b and c). Accordingly, with increased soil depth, the isotope value decreased gradually to a relatively constant value in all sampling sites, indicating that evaporation had little or no impact on the soil water within the deep soil layers.

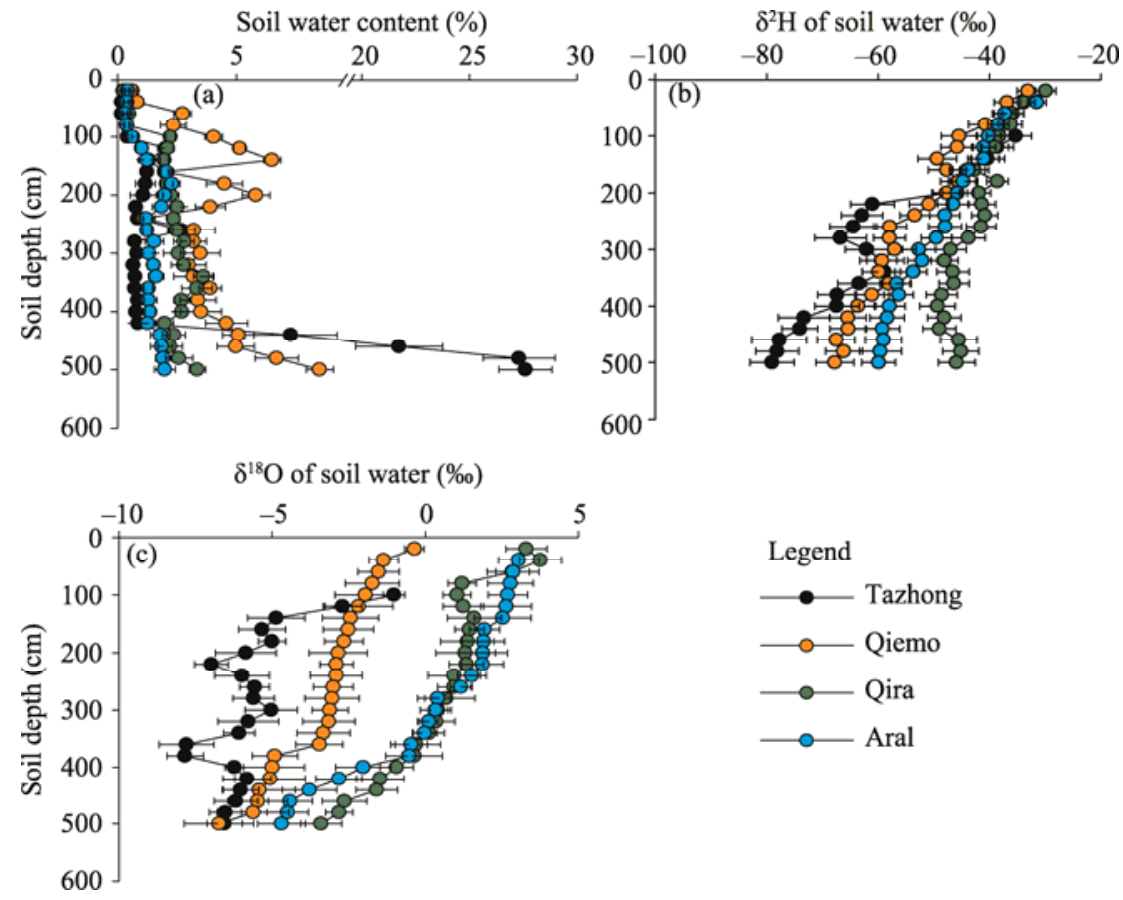

Fig. 4 Vertical distributions of soil water content (a), $\delta^{2} \mathrm{H}(\mathrm{b})$ and $\delta^{18} \mathrm{O}(\mathrm{c})$ values of soil water within the $T$. taklamakanensis nabkhas in the Tazhong, Qiemo, Qira and Aral sampling sites $(n=4)$. Bars mean standard errors.

In the Taklimakan Desert, the mean annual precipitation was very low, so the influences of precipitation on the shallow soil water and the stable isotope ratios of soil water were very small (Liu et al., 2006; Si et al., 2014). In the Tazhong and Qiemo sites, the $\delta^{2} \mathrm{H}$ and $\delta^{18} \mathrm{O}$ of soil water within the 0-200 cm soil depth were more enriched than those within the $200-500 \mathrm{~cm}$ soil depth $(P<0.05)$. In addition, the isotope values of soil water in the Tazhong and Qiemo sites were more depleted (especially in the deep soil layers) than the values in the Qira and Aral sites (Figs. $4 \mathrm{~b}$ and c). The isotope values of soil water decreased with soil depth, and the isotope values of deep soil water similar to the values of groundwater in the Tazhong and Qiemo sites (Figs. 4 and 5), which demonstrated that soil water was recharged by groundwater. In the Qira and Aral sites, the groundwater depth may have declined due to the excessive exploitation and utilization of water resources in populated areas (Fan et al., 2013; Zeng et al., 2013). The $\delta^{2} \mathrm{H}$ and $\delta^{18} \mathrm{O}$ values of soil water within the $0-500 \mathrm{~cm}$ soil depth showed significant variations $(P<0.05)$. Specifically, the $\delta^{18} \mathrm{O}$ values of soil water were more enriched within the $0-200 \mathrm{~cm}$ soil depth than within the $200-400 \mathrm{~cm}$ soil depth, and the values were progressively decreased and reached the relative minimum within the $400-500 \mathrm{~cm}$ soil depth (Fig. 4c). In addition, the $\delta^{2} \mathrm{H}: \delta^{18} \mathrm{O}$ ratios of soil water deviated to the right of the $\delta^{2} \mathrm{H}: \delta^{18} \mathrm{O}$ ratios of groundwater (Figs. $5 \mathrm{c}$ and $\mathrm{d}$ ). Therefore, there was no indication that soil water was recharged by groundwater in the soil depth above $500 \mathrm{~cm}$ in the Qira and Aral sites, inferring that the variations in stable isotope values of soil water were affected by evaporation and groundwater depth in these sites. 


\subsection{Stable isotope ratios of groundwater and possible groundwater recharge sources}

The global meteoric water line (GMWL: $\delta^{2} \mathrm{H}=8 \delta^{18} \mathrm{O}+10$; Craig, 1961), the local meteoric water line (LMWL: $\delta^{2} \mathrm{H}=7.27 \delta^{18} \mathrm{O}+6.47, R^{2}=0.94$; Zhou et al., 2017), and the $\delta^{2} \mathrm{H}: \delta^{18} \mathrm{O}$ ratios of soil water, snowmelt water, groundwater and plant xylem water were plotted in Figure 5.
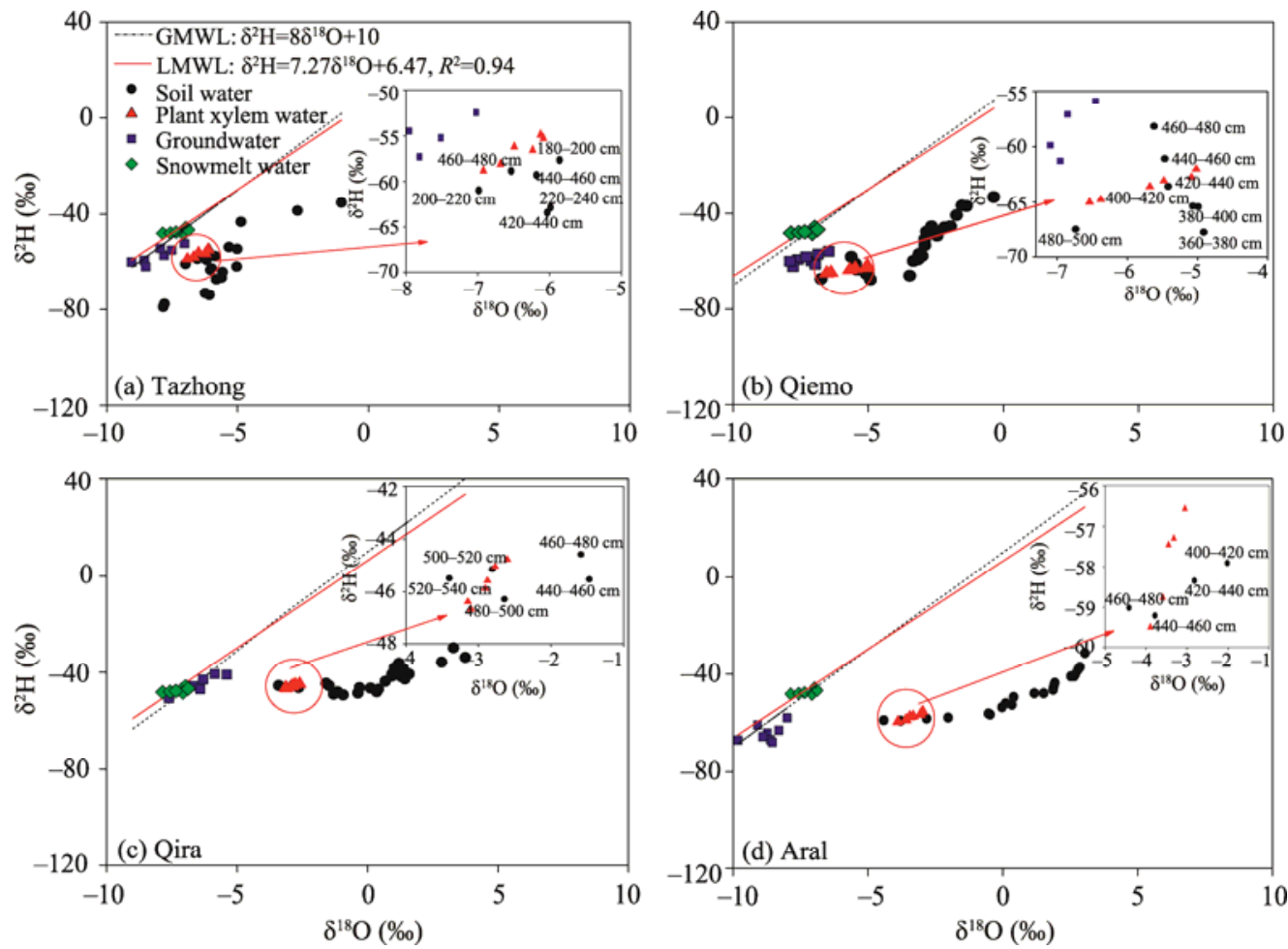

Fig. 5 Relationships between $\delta^{2} \mathrm{H}$ and $\delta^{18} \mathrm{O}$ in snowmelt water $(n=6)$, soil water $(n=4)$, groundwater $(n=6)$ and plant xylem water $(n=6)$ within the $T$. taklamakanensis nabkhas in the Tazhong (a), Qiemo (b), Qira (c) and Aral (d) sampling sites. All samples were taken during the rainless periods. Values of groundwater and snowmelt water represented long-term averages for each sampling site.

The $\delta^{2} \mathrm{H}: \delta^{18} \mathrm{O}$ ratios of snowmelt water were well matched with the LMWL, which indicated that a proportion of the precipitation was primarily contributed by the local snowmelt water (Fig. 5). The $\delta^{2} \mathrm{H}: \delta^{18} \mathrm{O}$ ratios of groundwater deviated to the right of the GMWL and LMWL in the Qiemo site (Fig. 5b). The $\delta^{2} \mathrm{H}: \delta^{18} \mathrm{O}$ ratios of groundwater samples were lower than those of snowmelt water samples (Fig. 5b), but the $\delta^{18} \mathrm{O}$ values of groundwater were similar to those of snowmelt water (Table 2). Nevertheless, the $\delta^{2} \mathrm{H}: \delta^{18} \mathrm{O}$ ratios of groundwater were close to the GMWL and LMWL in the Tazhong, Qira and Aral sites, but the $\delta^{2} \mathrm{H}$ and $\delta^{18} \mathrm{O}$ values of groundwater were higher than those of snowmelt water in the Tazhong and Aral sites (Figs. 5a, c and d; Table 2). This suggests that groundwater can be recharged by snowmelt water runoff.

Ehleringer and Dawson (1992) previously showed that the isotope composition of groundwater was a weighted average of long-term rainfall inputs. Moreover, Mathieu and Bariac (1996) indicated that the recharge processes of groundwater could be divided into two segments: (1) slow infiltration through the soil matrix and the weathered basement; and (2) fast and direct recharge through conducting fissured zones. In this study, we found that the above theory was not completely suitable for the Taklimakan Desert because the mean annual precipitation was very low in this region (Fig. 2) and the rainfall is often totally evaporated before infiltrating into the soil. Therefore, the infrequent precipitation almost exhibits no effect on the growth of plants, and the direct recharge of groundwater by precipitation is probably uncommon. However, groundwater can be also recharged by river runoff from precipitation in nearby mountains in this region (Liu et al., 2012). 


\subsection{Stable isotope ratios of plant xylem water and possible sources contributing to plant xylem water}

The $\delta^{2} \mathrm{H}: \delta^{18} \mathrm{O}$ ratios of soil water and plant xylem water deviated to the right of the GMWL and LMWL in all sampling sites (Fig. 5). This deviation indicated that plant xylem water and soil water were affected by strong evaporation due to the extremely dry climate conditions. The $\delta^{18} \mathrm{O}$ values of plant xylem water were more depleted in the Tazhong and Qiemo sites than in the Qira and Aral sites. However, the $\delta^{2} \mathrm{H}$ values of plant xylem water were more depleted in the Qiemo site than in the other three sites. In the Tazhong, Qiemo and Qira sites, the $\delta^{2} \mathrm{H}$ values of plant xylem water were similar to those of groundwater, and the $\delta^{18} \mathrm{O}$ values of plant xylem water were more enriched than those of groundwater in all sampling sites. The $\delta^{2} \mathrm{H}$ and $\delta^{18} \mathrm{O}$ values of plant xylem water in the Aral site were more enriched than those of groundwater (Table 2). In addition, Cleverly et al. (2002) indicated that the SWC in the surface soil layer was reduced to low levels, and may become inaccessible to the plants under the extremely dry climate conditions. In our study, the $\delta^{2} \mathrm{H}$ and $\delta^{18} \mathrm{O}$ values of plant xylem water were significantly more depleted than those of soil water within the shallow soil depth. Furthermore, the SWC was very low within the shallow soil depth $(0-200 \mathrm{~cm})$ in all sampling sites (Fig. 4). The low SWC were scarcely accessible to T. taklamakanensis and enriched isotope values of shallow soil water were little observed within the plant xylem water.

Table 2 Stable isotope ratios of plant xylem water, groundwater and snowmelt water

\begin{tabular}{|c|c|c|c|c|c|c|}
\hline \multirow{2}{*}{ Site } & \multicolumn{2}{|c|}{ Plant xylem water } & \multicolumn{2}{|c|}{ Groundwater } & \multicolumn{2}{|c|}{ Snowmelt water } \\
\hline & $\delta^{2} \mathrm{H}(\%)$ & $\delta^{18} \mathrm{O}(\% 0)$ & $\delta^{2} \mathrm{H}(\%)$ & $\delta^{18} \mathrm{O}(\% 0)$ & $\delta^{2} \mathrm{H}(\%)$ & $\delta^{18} \mathrm{O}(\%)$ \\
\hline Tazhong & $-56.648(0.631)$ & $-6.424(0.136)$ & $-57.332(1.308)$ & $-8.060(0.261)$ & \multirow{4}{*}{$-47.463(0.407)$} & \multirow{4}{*}{$-7.285(0.155)$} \\
\hline Qiemo & $-63.547(0.478)$ & $-5.697(0.261)$ & $-59.232(0.749)$ & $-7.242(0.176)$ & & \\
\hline Qira & $-45.718(0.304)$ & $-2.899(0.083)$ & $-37.042(0.929)$ & $-6.472(0.243)$ & & \\
\hline Aral & $-57.493(0.608)$ & $-3.378(0.141)$ & $-64.188(1.202)$ & $-8.745(0.194)$ & & \\
\hline
\end{tabular}

Note: Values in the brackets indicate standard errors.

In this study, field sampling was conducted during the summer (July), the precipitation was judged to be non-significant for plant growth because of the extremely rare precipitation in summer (Chen et al., 2003), and typically no water was found to be stored within the surface soil layer (Fig. 2; Thomas et al., 2008). The potential sources of plant xylem water were identified by employing a Bayesian isotope mixing model, and the results are shown in Figure 6. Furthermore, the probability density graphs for each end-member were also indicated, which were superimposed on the graphs of their relative contributions to plant xylem water. Yakir and Yechieli (1995) showed that plants may differentially utilize water from the soil water of different depths. The use of potential water sources may be an adaptive selection by desert plants to improve their survival under the extremely dry climate conditions (Tiemuerbieke et al., 2018). Therefore, plant xylem water is likely to represent a mixture of different water sources.

T. taklamakanensis indicated a shift in water use strategy among the different habitats. In the Tazhong site, the $\delta^{2} \mathrm{H}: \delta^{18} \mathrm{O}$ ratios of plant xylem water were similar to the values of soil water in the soil depths of 180-240 cm and below $420 \mathrm{~cm}$ and in the layer of groundwater (Fig. 5a). Furthermore, the contributions of shallow, middle and deep soil water and groundwater to the xylem water of $T$. taklamakanensis plants were $10 \%( \pm 2 \%), 23 \%( \pm 1 \%), 31 \%( \pm 5 \%)$ and $36 \%$ $( \pm 2 \%)$ in this site, respectively (Fig. 6). These results indicated that T. taklamakanensis, growing in the sandy desert habitat, had water sources that originated from the multi-layer soil water and groundwater. Nevertheless, due to the extremely rare precipitation and very strong evaporation (Fig. 2 ), the plant cover in the T. taklamakanensis nabkha was very low, the SWC within the shallow and middle soil layers was extremely low $(<1 \%$; Fig. 4$)$, and thus the plants cannot utilize the soil water from the shallow soil layer. The groundwater depth was relatively shallow $(5.0-6.0 \mathrm{~m})$ in the Tazhong site (Table 1). Groundwater can recharge the deep soil water due to capillary action (Zhao et al., 2010). Furthermore, we also found that T. taklamakanensis had a developed absorption root 
system below the $200 \mathrm{~cm}$ soil depth, and the root system can even extend the soil depth of below 500 $\mathrm{cm}$ (Fig. 7). Therefore, we inferred that middle and deep soil water and groundwater were the primary water sources of xylem water of $T$. taklamakanensis plants in the Taklimakan Desert.

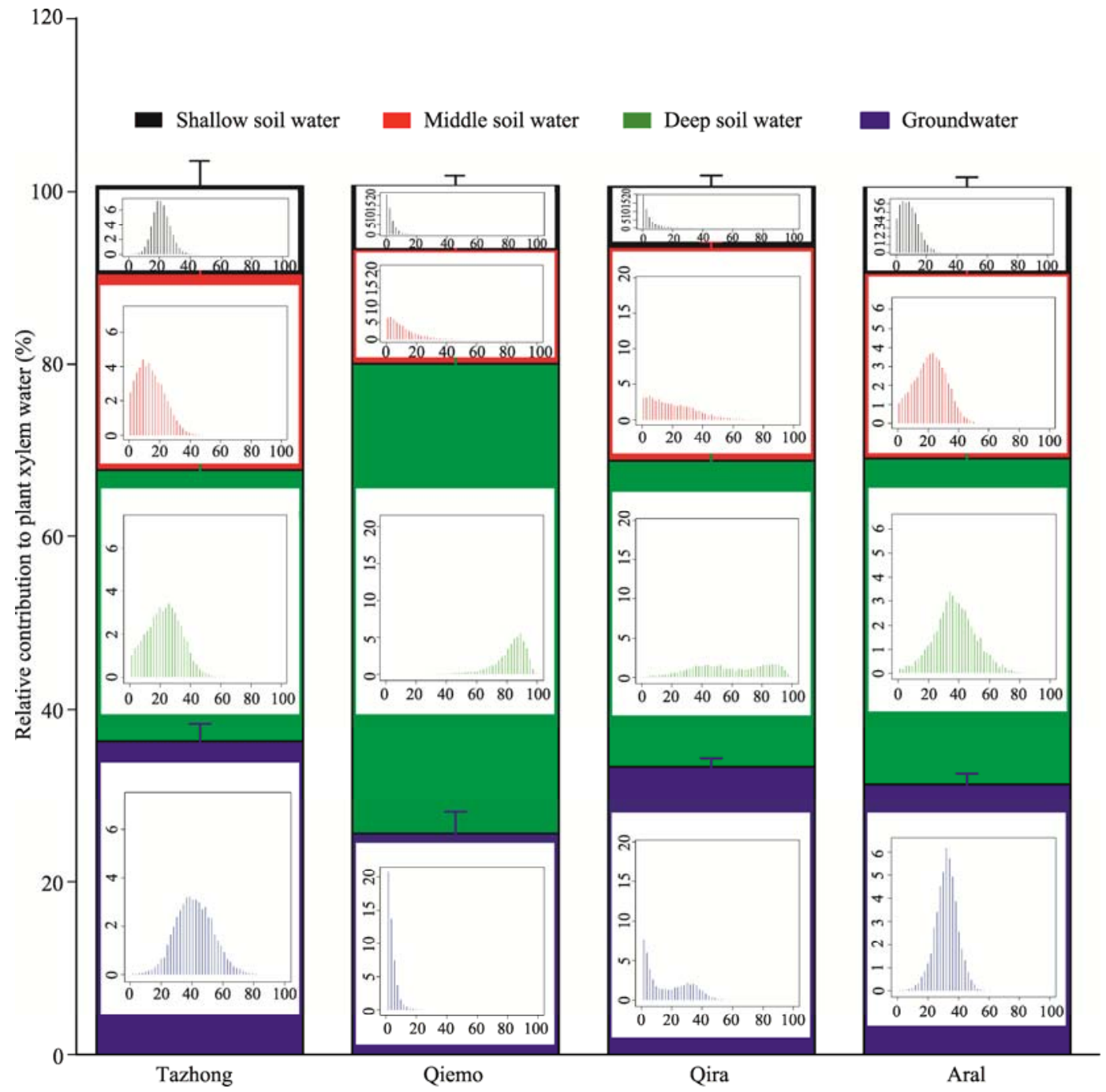

Fig. 6 Relative contributions of shallow, middle and deep soil water and groundwater to the xylem water of $T$. taklamakanensis plants based on the Bayesian isotope mixing model. The respective probability density proportion plots of each possible water source (where the $x$ axis represents the contribution of each possible water source to plant xylem water (\%) and the $y$ axis represents the frequency (\%)) are superimposed on the plots of relative contributions of different water sources to the xylem water of T. taklamakanensis plants. Error bars represent standard errors. The patches of black, red, green and blue represent the relative contributions of shallow soil water, middle soil water, deep soil water and groundwater to the xylem water of $T$. taklamakanensis plants, respectively.

In the Qiemo site, T. taklamakanensis nabkhas were mainly distributed in the transition zone between the alluvial plain and the desert. The $\delta^{2} \mathrm{H}: \delta^{18} \mathrm{O}$ ratios of plant xylem water were similar to the values observed for groundwater and soil water below the soil depth of $360 \mathrm{~cm}$ (Fig. 5b). The contribution of deep soil water to the xylem water of T. taklamakanensis plants was $55 \%( \pm 4 \%)$, and the contributions of shallow and middle soil water and groundwater were $7 \%( \pm 1 \%), 13 \%( \pm 1 \%)$ and $25 \%( \pm 2 \%)$, respectively (Fig. 6). This suggested that plant xylem water was mainly derived from the deep soil water and following the groundwater. Additionally, in the Qiemo site, the surface soil layer had thick salt crusts due to the flood alluvium and evaporation in summer and the groundwater depth was shallow $(4.5-5.5 \mathrm{~m})$, resulting in the SWC was relatively high and the plant cover was 
also relatively high (50\%). These findings further confirmed that $T$. taklamakanensis mainly used the deep soil water and groundwater in this saline desert-alluvial plain habitat.

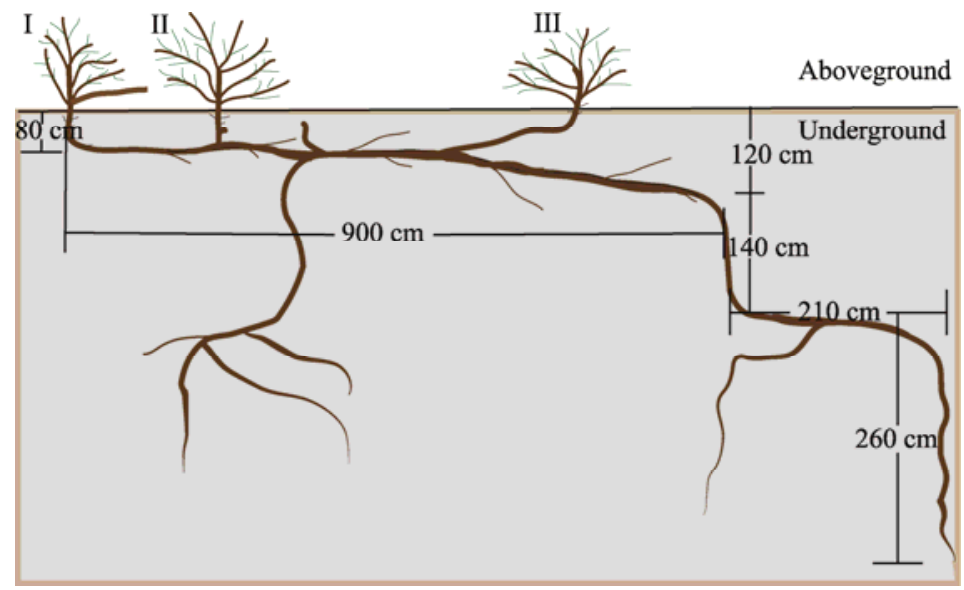

Fig. 7 Sketch of root distribution in the profiles of different T. taklamakanensis plants (I, II and III) in the same T. taklamakanensis nabkha

In the Qira site, the $\delta^{2} \mathrm{H}: \delta^{18} \mathrm{O}$ ratios of plant xylem water were most similar to those of soil water below the soil depth of $480 \mathrm{~cm}$ (Fig. 5c). Moreover, the contribution of deep soil water to the xylem water of T. taklamakanensis plants accounted for a large proportion of water utilization, with the percentage of $35 \%( \pm 1 \%)$, and the contributions of shallow and middle soil water and groundwater were $7 \%( \pm 1 \%), 25 \%( \pm 1 \%)$ and $33 \%( \pm 1 \%)$, respectively (Fig. 6). In the Aral site, the $\delta^{2} \mathrm{H}: \delta^{18} \mathrm{O}$ ratios of plant xylem water were more enriched than those of groundwater, and they were most similar to those observed for soil water below the soil depth of $400 \mathrm{~cm}$ (Fig. $5 \mathrm{~d}$ ). The contribution of deep soil water $38 \%( \pm 2 \%)$ constituted the largest percentage of xylem water of $T$. taklamakanensis plants. The contributions of shallow and middle soil water and groundwater were $9 \%( \pm 2 \%), 22 \%$ $( \pm 1 \%)$ and $31 \%( \pm 1 \%)$, respectively (Fig. 6). However, previous studies indicated that the groundwater depth in the Qira and Aral sites was 11.0-16.0 and 8.0-10.0 m, respectively (Fan et al., 2013; Zeng et al., 2013). Li et al. (2009) showed that T. taklamakanensis could not survive when the groundwater depth was more than $15.7 \mathrm{~m}$. Furthermore, T. taklamakanensis nabkhas were relatively high in the Qira and Aral sites (Table 1). This suggested that deep soil water was the primary water source of $T$. taklamakanensis in the desert-oasis ecotone habitat, and that groundwater may also be an essential water source.

Since the groundwater depth was relatively deep in the Qira and Aral sites, we inferred that soil water cannot be completely recharged by groundwater. This result may be partially explained by the locations of the Qira and Aral sites, where the water resource demands have been continuously increasing such that the groundwater depth may be in decline. In addition, T. taklamakanensis nabkhas were higher in the Qira site than in the Aral site, and the groundwater depth in the Qira site was deeper than that in the Aral site. This also partly explained why T. taklamakanensis can absorb soil water below the depth of $480 \mathrm{~cm}$ in the Qira site while absorb soil water below the depth of 400 $\mathrm{cm}$ in the Alar site. These findings confirmed that T. taklamakanensis can tolerate the arid environment. Furthermore, these results supported our hypothesis that $T$. taklamakanensis utilizes the middle and deep soil water and/or groundwater, and demonstrated that the roots of $T$. taklamakanensis in the surface soil layer may be inactive because of the low SWC. This inactivation seems to be an adaptive choice of plants under dry and water-deficient conditions in the desert environment.

\subsection{Implication of T. taklamakanensis nabkhas}

Groundwater and deep soil water were the dominant water sources for the survival of plants in the Taklimakan Desert, where the groundwater depth ranged from 3.0 to $15.0 \mathrm{~m}$ (Zeng et al., 2013). Most T. taklamakanensis nabkhas were primarily distributed within the fringe regions of the 
Taklimakan Desert, and the height and length of these nabkhas ranged from 3.00 to $15.00 \mathrm{~m}$ and from 5.00 to $50.00 \mathrm{~m}$ (long axis), respectively (Muhtar et al., 2002). In the study sites, the average height and length of T. taklamakanensis nabkhas were about 3.00 and $7.00 \mathrm{~m}$, respectively. T. taklamakanensis can grow on the high sand dunes and primarily utilize deep soil water and groundwater to maintain their survival and meet their growth needs. Nevertheless, as the height of $T$. taklamakanensis nabkhas increased (above $15.00 \mathrm{~m}$ ) and the groundwater depth dropped to below the extent of the roots, T. taklamakanensis nabkhas may begin degenerating and T. taklamakanensis plants may die, which will intensify the desertification (Xia et al., 2004). Groundwater depth did not limit their survival and growth in this study. Therefore, T. taklamakanensis nabkhas may reflect the changes in the groundwater depth and may also act as indicators of environmental change in the desert environment.

Horton and Clark (2001) showed that T. taklamakanensis may not only obtain groundwater through the deep roots but also can acquire water from the unsaturated areas of soil (Cleverly et al., 2002). Gries et al. (2003) indicated that T. taklamakanensis was established by the germination of plant seed in the lowland zones and can also be established through clonal growth in the crests and slopes of the sand dunes (Muhtar et al., 2002). During the filed sampling, we found that $T$. taklamakanensis was established through clonal growth, and its taproots extended horizontally by a certain distance and then gradually extended downward (Fig. 7). Furthermore, we found that in the same T. taklamakanensis nabkha, several T. taklamakanensis plants within a certain distance shared the same taproot system (Fig. 7). These results also confirmed the reasons for the capability of $T$. taklamakanensis to grow on the high sand dunes.

\section{Conclusions}

In this study, we used the stable isotope analysis to investigate the water use strategies of $T$. taklamakanensis growing on the T. taklamakanensis nabkhas in the different habitats. In the Taklimakan Desert, groundwater was recharged by the river runoff from snowmelt water in nearby mountain ranges. T. taklamakanensis growing in the different habitats had different water use strategies and they can change their water use patterns according to the climate characteristics, size of T. taklamakanensis nabkha, groundwater depth, plant cover and soil texture. In the sandy desert habitat, where the surface SWC was depleted, T. taklamakanensis primarily utilized the middle and deep soil water and groundwater. In the saline desert-alluvial plain habitat, where the SWC increased with soil depth, T. taklamakanensis mainly utilized the deep soil water and following the groundwater. In the desert-oasis ecotone, T. taklamakanensis primarily utilized the deep soil water and may also use groundwater. Thus, the potential water sources of T. taklamakanensis were largely dependent on the groundwater depth and specific habitats. The water use strategies of $T$. taklamakanensis mirrored its adaptation to different habitats in the desert ecosystem.

\section{Acknowledgements}

This work was supported by the "Research and Development of Sand Prevention Technology of Highway and Soil Erosion Control Technology of Pipelines" of the Strategic Priority Research Program of the Chinese Academy of Sciences "Environmental Changes and Silk Road Civilization in Pan-Third Pole Region" (XDA2003020201), the Key Inter-governmental Projects for International Scientific and Technological Innovation Cooperation of the National Key Research and Development Program of China: "China-Mongolia Cooperation Research and Demonstration in Grassland Desertification Control Technology" (2017YFE0109200), the National Natural Science Foundation of China (41571011, 31971731, U1703102), the Key Technical Personnel (Y932111) and the Thousand Youth Talents Plan Project (Y472241001). The authors would like to thank the Taklimakan Desert Research Station for field and laboratory assistances.

\section{References}

Bruelheide H, Jandt U, Gries D, et al. 2003. Vegetation changes in a river oasis on the southern rim of the Taklamakan Desert in China between 1956 and 2000. Phytocoenologia, 33(4): 801-818. 
Chen Y N, Cui W C, Li W H, et al. 2003. Utilization of water resources and ecological protection in the Tarim River. Acta Geographica Sinica, 58(2): 215-222. (in Chinese)

Cleverly J R, Dahm C N, Thibault J R, et al. 2002. Seasonal estimates of actual evapo-transpiration from Tamarix ramosissima stands using three-dimensional eddy covariance. Journal of Arid Environments, 52(2): 181-197.

Craig H. 1961. Isotopic variations in meteoric water. Science, 133(3465): 1702-1703.

Cui Y Q, Ma J Y, Sun W, et al. 2015. A preliminary study of water use strategy of desert plants in Dunhuang, China. Journal of Arid Land, 7(1): 73-81.

Dai Y, Zheng X J, Tang L S et al. 2015. Stable oxygen isotopes reveal distinct water use patterns of two Haloxylon species in the Gurbantonggut Desert. Plant and Soil, 389(1-2): 73-87.

Dawson T E, Mambelli S, Plamboeck A H. 2002. Stable isotopes in plant ecology. Annual Review of Ecology and Systematics, 33 : $507-559$.

Dong Z W, Zhao Y, Lei J Q, et al. 2018. Distribution pattern and influencing factors of soil salinity at Tamarix cones in the Taklimakan Desert. Chinese Journal of Plant Ecology, 42(8): 873-884. (in Chinese)

Ehleringer J R, Dawson T E. 1992. Water uptake by plants: perspectives from stable isotope composition. Plant Cell and Environment, 15(9): 1073-1082.

Evaristo J, McDonnell J J, Scholl M A, et al. 2016. Insights into plant water uptake from xylem-water isotope measurements in two tropical catchments with contrasting moisture conditions. Hydrological Processes, 30(18): 3210-3227.

Fan J L, Jin X J, Lei J Q, et al. 2013. Responses of ground water level to pumping water of the Tarim Desert Highway shelterbelt project. Chinese Agricultural Science Bulletin, 29(2): 114-119. (in Chinese)

Gat J R, Yakir D, Goodfriend G, et al. 2007. Stable isotope composition of water in desert plants. Plant and Soil, 298(1-2): 31-45.

Gong W H, Wang Y G, Gao Q Z, et al. 2011. Ecological comprehensive monitoring for Aral Station in Tarim River Basin. Arid Land Geography, 34(5): 762-771. (in Chinese)

Gries D, Zeng F, Foetzki A, et al. 2003. Growth and water relations of Tamarix ramosissima and Populus euphratica on Taklamakan desert dunes in relation to depth to a permanent water table. Plant Cell and Environment, 26(5): 725-736.

Horton J L, Clark J L. 2001. Water table decline alters growth and survival of Salix gooddingii and Tamarix chinensis seedlings. Forest Ecology and Management, 140(2-3): 239-247.

Li H S, Wang W F, Zhan H T, et al. 2010. New judgement on the source of soil water in extremely dry zone. Acta Ecologica Sinica, 30(1): 1-7.

Li S Y, Tang Q L, Lei J Q, et al. 2015. An overview of non-conventional water resource utilization technologies for biological sand control in Xinjiang, northwest China. Environment Earth Science, 73(2): 873-885.

Li X Y, Lin L S, Zhao Q. 2009. Distribution of dominant plant species and characteristic of its communities on the foreland of Cele oasis in relation to groundwater level. Arid Land Geography, 32(6): 906-911. (in Chinese)

Liu X P, Zhang T H, Zhao H L, et al. 2006. Infiltration and redistribution process of rainfall in desert mobile sand dune. Journal of Hydraulic Engineering, 37(2): 166-171. (in Chinese)

Liu X Y, Mao J T, Zhang F, et al. 2012. The analysis of water vapor distribution over Taklimakan Desert. Science China Earth Sciences, 55(3): 446-455. (in Chinese)

Mathieu R, Bariac T. 1996. An isotopic study $\left({ }^{2} \mathrm{H}\right.$ and $\left.{ }^{18} \mathrm{O}\right)$ of water movements in clayey soils under a semiarid climate. Water Resources Research, 32(4): 779-790.

Muhtar Q, Hiroki T, Mijit H. 2002. Formation and internal structure of Tamarix cones in the Taklimakan Desert. Journal of Arid Environments, 50(1): 81-97.

Parnell A C, Inger R, Bearhop S, et al. 2010. Source partitioning using stable isotopes: coping with too much variation. PloS ONE, 5: e9672.

Rosenthal D M, Ludwig F, Donovan L A. 2005. Plant responses to an edaphic gradient across an active sand dune/desert boundary in the Great Basin Desert. International Journal of Plant Sciences, 166(2): 247-255.

Schachtschneider K, February E C. 2010. The relationship between fog, floods, groundwater and tree growth along the lower Kuiseb River in the hyperarid Namib. Journal of Arid Environments, 74(12): 1632-1637.

Schultz N M, Griffis T J, Lee X H, et al. 2011. Identification and correction of spectral contamination in ${ }^{2} \mathrm{H} /{ }^{1} \mathrm{H}$ and ${ }^{18} \mathrm{O} /{ }^{16} \mathrm{O}$ measured in leaf, stem, and soil water. Rapid Communications in Mass Spectrometry, 25(21): 3360-3368.

Si J H, Feng Q, Cao S, et al. 2014. Water use sources of desert riparian Populus euphratica forests. Environmental Monitoring and Assessment, 186(9): 5469-5477.

Sun J M, Liu T S. 2006. The age of the Taklimakan Desert. Science, 312(5780): 1621, doi: 10.1126/science.1124616.

Sun Z Y, Long X, Ma R. 2016. Water uptake by saltcedar (Tamarix ramosissima) in a desert riparian forest: responses to intra-annual water table fluctuation. Hydrological Processes, 30(9): 1388-1402. 
Thomas T W. 2008. Desert Meteorology. New York: Cambridge University Press, 136: 143-151.

Tiemuerbieke B, Min X J, Zang Y X, et al. 2018. Water use patterns of co-occurring $\mathrm{C}_{3}$ and $\mathrm{C}_{4}$ shrubs in the Gurbantonggut desert in northwestern China. Science of The Total Environment, 634: 341-354.

Wang S G, Wang J Y, Zhou Z J, et al. 2005. Regional characteristics of three kinds of dust storm events in China. Atmospheric Environment, 39(3): 509-520.

Wang Y Y, Chen Y P, Li W H, et al. 2017. Water sources of typical desert riparian plants in the lower reaches of Tarim River. Journal of Desert Research, 37(6): 1150-1157. (in Chinese)

Wu H W, Li X Y, Jiang Z Y, et al. 2016. Contrasting water use pattern of introduced and native plants in an alpine desert ecosystem, Northeast Qinghai-Tibet Plateau, China. Science of The Total Environment, 542: 182-191.

Wu Y, Zhou H, Zheng X J, et al. 2014. Seasonal changes in the water use strategies of three co-occurring desert shrubs. Hydrological Processes, 28(26): 6265-6275.

Xia X C, Zhao Y J, Wang F B. 2004. Stratification features of Tamarix cone and its possible age significance. Chinese Science Bulletin, 49(14): 1539-1540. (in Chinese)

Yakir D, Yechieli Y. 1995. Plant invasion of newly exposed hypersaline Dead Sea shores. Nature, 374: 803-805.

Zeng F J, Song C, Guo H, et al. 2013. Responses of root growth of Alhagi sparsifolia Shap. (Fabaceae) to different simulated groundwater depths in the southern fringe of the Taklimakan Desert, China. Journal of Arid Land, 5(2): 220-232.

Zhang D Y, Pan B R, Yin L K. 2003. The photo geographical studies of Tamarix (Tamaricaceae). Acta Botanica Yunnanica, 25: 415-427. (in Chinese)

Zhang J H, Wang N A, Niu Z M, et al. 2018. Stable isotope analysis of water sources for Tamarix laxa in the mega-dunes of the Badain Jaran Desert, China. Journal of Arid Land, 10(6): 821-832.

Zhao J B, Ma Y D, Xing S H, et al. 2010. Study on moisture content in sand layers of Tengger Desert in Zhongwei, Ningxia. Journal of Mountain Science, 28(6): 653-659. (in Chinese)

Zhou H, Zheng X J, Tang L S, et al. 2013. Differences and similarities between water sources of Tamarix ramosissima, Nitraria sibirica and Reaumuria soongorica in the southeastern Junggar Basin. Chinese Journal of Plant Ecology, 37(7): 665-673. (in Chinese)

Zhou T H, Zhao C Y, Wu G L, et al. 2017. Application of stable isotopes in analyzing the water source of Populus euphratica and Tamarix ramosissima in the upstream of Tarim River. Journa1 of Desert Research, 37(1): 124-131. (in Chinese) 